\title{
Bulking up: Hexanuclear oximato Fe(III) complexes surrounded by sterically demanding co-ligands
}

Houton, E.; Meally, S.T.; Sanz, S.; Brechin, E.K.; Jones, L.F.

\section{Inorganica Chimica Acta}

\author{
DOI: \\ 10.1016/j.ica.2014.06.021
}

Published: 01/09/2014

Peer reviewed version

Cyswllt i'r cyhoeddiad / Link to publication

Dyfyniad o'r fersiwn a gyhoeddwyd / Citation for published version (APA):

Houton, E., Meally, S. T., Sanz, S., Brechin, E. K., \& Jones, L. F. (2014). Bulking up:

Hexanuclear oximato Fe(III) complexes surrounded by sterically demanding co-ligands. Inorganica Chimica Acta, 421, 416-422. https://doi.org/10.1016/j.ica.2014.06.021

\footnotetext{
Hawliau Cyffredinol / General rights

Copyright and moral rights for the publications made accessible in the public portal are retained by the authors and/or other copyright owners and it is a condition of accessing publications that users recognise and abide by the legal requirements associated with these rights.

- Users may download and print one copy of any publication from the public portal for the purpose of private study or research

- You may not further distribute the material or use it for any profit-making activity or commercial gain

- You may freely distribute the URL identifying the publication in the public portal ?
}

Take down policy

If you believe that this document breaches copyright please contact us providing details, and we will remove access to the work immediately and investigate your claim. 


\title{
Bulking Up: Hexanuclear Oximato Fe(III) Complexes Surrounded by Sterically Demanding Co-Ligands
}

\author{
Edel Houton, ${ }^{a}$ Sean T. Meally, ${ }^{a}$ Sergio Sanz, ${ }^{b}$ Euan K. Brechin ${ }^{b}$ and Leigh F. Jones. ${ }^{a}+\underset{f}{f}$ \\ \$ Current address: School of Chemistry, Bangor University, Bangor, Wales. LL57 2DG. Tel: +44- \\ (0)1248-38-2391.Email: leigh.jones@bangor.ac.uk \\ ${ }^{a}$ School of Chemistry, NUI Galway, University Road, Galway, Ireland. \\ ${ }^{b}$ EaStCHEM School of Chemistry, University of Edinburgh, West Mains Road, Edinburgh, EH9 3JJ, \\ Scotland.
}

\begin{abstract}
Despite their inherent steric bulk, a combination of 2-hydroxy-1-naphthaldoxime $\left(\mathrm{L}_{1} \mathrm{H}_{2}\right)$ with polyphenolic carboxylate ligands (1-Naphthoate, 9-Anthracene carboxylate) aid the construction and stabilisation of hexanuclear arrays of $\mathrm{Fe}(\mathrm{III})$ ions in the form of $\left[\mathrm{Fe}(\mathrm{III})_{6} \mathrm{O}_{2}\left(\mathrm{~L}_{1}\right)_{2}\left(\mathrm{O}_{2} \mathrm{C}-\mathrm{R}\right)_{10}\left(\mathrm{H}_{2} \mathrm{O}\right)_{2}\right] \cdot 8 \mathrm{MeCN}\left(\mathrm{R}=\right.$ Naphth- $\left(\mathrm{C}_{10} \mathrm{H}_{8}\right)(\mathrm{I}) ; \mathrm{R}=$ Anthra- $\left(\mathrm{C}_{14} \mathrm{H}_{9}\right)$ (2)). Likewise, the sterically hindered ligand 3,5-di-tert-butyl-salicylaldoxime $\left(\mathrm{L}_{2} \mathrm{H}_{2}\right)$ is able to aid the self-assembly of the tetranuclear, cubane-like species [Fe(III $\left.)_{4}\left(\mathrm{~L}_{2}\right)_{4}(\mathrm{MeOH})_{4}(\mathrm{Cl})_{4}\right]$ (3). Magnetic susceptibility studies carried out on 1 and $\mathbf{3}$ reveal antiferromagnetic exchange between the $\mathrm{Fe}(I I I)$ metal centres affording $S=0$ ground spin states in both cases.
\end{abstract}

\section{Introduction}

Functionalised phenolic oximes have extensive application as ligands in the solvent extraction of copper, accounting for $c a .25 \%$ of worldwide production [1]. Complex stability upon binding is (at least in part) due to the formation of pseudo macrocyclic $\left[\mathrm{Cu}(\mathrm{L})_{2}\right]$ (where $\mathrm{L}=$ phenolic oxime) moieties. Recent studies by Forgan et al have shown that extractant strength may be tuned by controlling the extent of outer sphere $\mathrm{H}$-bonding interactions [2]. Although exhibiting a great affinity towards copper, oximes have also formed many interesting [often polymetallic] coordination complexes with other $1^{\text {st }}$ row transition metals $[3,4]$. A good example is the use of derivatised salicyaldoximes ( $\mathrm{R}-\mathrm{saoH}_{2} ; \mathrm{R}=\mathrm{H}, \mathrm{Me}, \mathrm{Et}, \mathrm{Ph}$,

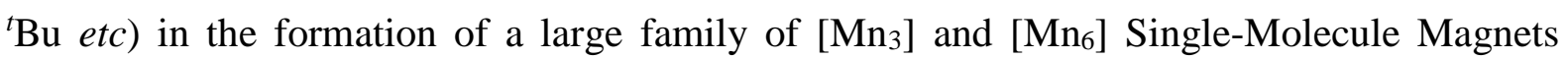
(SMMs) [5]. Moreover it was shown inextricably that the ground spin states of these magnetic cages could be tuned and controlled by modification of the bridging salicyaldoxime ligands at their R positions [6]. Although $\left[\mathrm{Mn}_{3}\right]$ and $\left[\mathrm{Mn}_{6}\right]$ cage formation was found to be 
predictable and under near complete synthetic control, investigations into the coordination chemistry of the same salicyaldoximes with iron has proven to be far more difficult and less predictable, giving rise to ferric cages of numerous sizes (ranging from $\left\{\mathrm{Fe}_{2}\right\}$ [7] to $\left\{\mathrm{Fe}_{12}\right\}$ [8]) and topologies, depending on specific synthetic factors, such as the type of oxime, the nature of the co-ligand (e.g. carboxylate), solvent identity, and temperature/pressure [9b].

With these thoughts in mind we decided to examine the role of sterically demanding oximes and carboxylate co-ligands towards Fe-oxime cage formation [10] and quickly settled on investigating combinations of 2-hydroxy-1-naphthaldoxime $\left(\mathrm{L}_{1} \mathrm{H}_{2}\right.$; Scheme 1) and the carboxylate anions 1-Naphthoate $\left({ }^{-} \mathrm{O}_{2}-\mathrm{C}-\mathrm{C}_{10} \mathrm{H}_{8}\right)$ and 9-Anthracenecarboxylate $\left({ }^{-} \mathrm{O}_{2} \mathrm{C}\right.$ $\left.\mathrm{C}_{12} \mathrm{H}_{10}\right)$ (Scheme 1). To this end we present the hexametallic siblings $\left[\mathrm{Fe}(\mathrm{III})_{6} \mathrm{O}_{2}\left(\mathrm{~L}_{1}\right)_{2}\left(\mathrm{O}_{2} \mathrm{C}\right.\right.$ $\left.\left.\mathrm{C}_{10} \mathrm{H}_{8}\right)_{10}\left(\mathrm{H}_{2} \mathrm{O}\right)_{2}\right] \cdot 8 \mathrm{MeCN}(\mathbf{1})$ and $\left[\mathrm{Fe}(\mathrm{III})_{6} \mathrm{O}_{2}\left(\mathrm{~L}_{1}\right)_{2}\left(\mathrm{O}_{2} \mathrm{C}-\mathrm{C}_{14} \mathrm{H}_{10}\right)_{10}\left(\mathrm{H}_{2} \mathrm{O}\right)_{2}\right] \cdot 8 \mathrm{MeCN}(2)$, and the tetranuclear cube-like cage $\left[\mathrm{Fe}(\mathrm{III})_{4}\left(\mathrm{~L}_{2}\right)_{4}(\mathrm{MeOH})_{4}(\mathrm{Cl})_{4}\right]$ (3) constructed using 3,5-di-tertbutyl salicyaldoxime $\left(\mathrm{L}_{2} \mathrm{H}_{2}\right.$, Scheme 1).<smiles>O/N=C/c1c(O)ccc2ccccc12</smiles>

B)<smiles>CC(C)(C)c1cc(O)c(/C=N/O)c(C(C)(C)C)c1</smiles>

C)<smiles>O=C(O)c1cccc2ccccc12</smiles>

D)<smiles>O=C(O)c1c2ccccc2cc2ccccc12</smiles>

Scheme 1: ChemDraw representations of the ligands 2-hydroxy-1-naphthaldoxime $\left(\mathrm{L}_{1} \mathrm{H}_{2} ; \mathbf{A}\right)$, 3,5-ditert-butyl-salicylaldoxime $\left(\mathrm{L}_{2} \mathrm{H}_{2} ; \mathbf{B}\right)$, 1-Naphthoic acid (C) and 9-Anthracene carboxylic acid (D).

\section{Experimental Section}

\subsection{Materials and physical measurements}


Infra-red spectra were recorded on a Perkin Elmer FT-IR Spectrum One spectrometer equipped with a Universal ATR Sampling accessory (NUI Galway). Elemental analysis was carried at the School of Chemistry microanalysis service at NUI Galway. Variabletemperature, solid-state direct current $(\mathrm{dc})$ magnetic susceptibility data down to $1.8 \mathrm{~K}$ were collected on a Quantum Design MPMS-XL SQUID magnetometer equipped with a $7 \mathrm{~T}$ dc magnet. Diamagnetic corrections were applied to the observed paramagnetic susceptibilities using Pascal's constants.

\subsection{Crystal structure information}

Complexes 1-3 were collected on an Xcalibur S single crystal diffractometer (Oxford Diffraction) using an enhanced Mo source (CCDC numbers: 999462 (1), 999463 (2) and 999461 (3)). Each data reduction was carried out on the CrysAlisPro software package. The structures were solved by direct methods (SHELXS-97) [11] and refined by full matrix least squares using SHELXL-97 [12]. SHELX operations were automated using the OSCAIL software package.[13] All hydrogen atoms in 1-3 were assigned to calculated positions. All non-hydrogen atoms were refined as anisotropic. A DFIX restraint was placed on a single MeCN solvent of crystallisation in 2 (labelled C93-C94-N5). Crystal data and refinement parameters are tabulated in Table 1. Single crystals of complex $\mathbf{2}$ were found to be weakly diffracting at higher angles and therefore several collections were attempted. Our best data set has been supplied in this work $(\mathrm{R} 1=0.1285)$.

\subsection{Synthetic Details}

All reactions were performed under aerobic conditions and all reagents and solvents were used as purchased. Ligands $\mathrm{L}_{1} \mathrm{H}_{2}$ and $\mathrm{L}_{2} \mathrm{H}_{2}$ were synthesised using literature methods [14].

\subsubsection{Synthesis of $\left[\mathrm{Fe}(\mathrm{III})_{6} \mathrm{O}_{2}\left(\mathrm{~L}_{1}\right)_{2}\left(\mathrm{O}_{2} \mathrm{C}-\mathrm{C}_{10} \mathrm{H}_{8}\right)_{10}\left(\mathrm{H}_{2} \mathrm{O}\right)_{2}\right] \cdot 8 \mathrm{MeCN}(\mathbf{1})$}

$\mathrm{FeCl}_{2} \cdot 4 \mathrm{H}_{2} \mathrm{O}(0.25 \mathrm{~g}, 1.26 \mathrm{mmol}), \mathrm{L}_{1} \mathrm{H}_{2}(0.235 \mathrm{~g}, 1.26 \mathrm{mmol})$, Sodium 1-Naphthoate (0.242 g, $1.25 \mathrm{mmol})$ and $\mathrm{NaOMe}(0.068 \mathrm{~g}, 1.26 \mathrm{mmol})$ were stirred in $\mathrm{MeOH}\left(30 \mathrm{~cm}^{3}\right)$ for $2 \mathrm{~h}$, filtered and allowed to evaporate to dryness. The resultant solid was dissolved in a $1: 1$ $\mathrm{MeCN}: \mathrm{CH}_{2} \mathrm{Cl}_{2}$ solvent mixture, filtered and left to stand. Dark red crystals of $\mathbf{1}$ were formed upon slow evaporation in $20 \%$ yield over a period of 5 days. Elemental analysis (\%) calculated (found) for $\mathrm{C}_{148} \mathrm{H}_{112} \mathrm{~N}_{10} \mathrm{O}_{28} \mathrm{Fe}_{6}$ : $\mathrm{C} 63.18$ (63.37), $\mathrm{H} 4.01$ (3.84); N 4.98 (4.55). FTIR $\left(\mathrm{cm}^{-1}\right)$ : 3051(w), 1617(w), 1597(w), 1578(w), 1541(m), 1525(m), $1509(\mathrm{~m}), 1459(\mathrm{w})$, 
1408(s), 1375(s), 1343(vs), 1257(m), 1209 (w), 1184(w), 1157(w), 1139(w), 1077(w), 1037(w), 1010(w), 998(w), 941(m), 870(vw), 826(w), 782(vs), 757(m), 750(m), 672(w).

\subsubsection{Synthesis of $\left[\mathrm{Fe}(\mathrm{III})_{6} \mathrm{O}_{2}\left(\mathrm{~L}_{1}\right)_{2}\left(\mathrm{O}_{2} \mathrm{C}-\mathrm{C}_{14} \mathrm{H}_{10}\right)_{10}\left(\mathrm{H}_{2} \mathrm{O}\right)_{2}\right] \cdot 8 \mathrm{MeCN}$ (2)}

$\mathrm{FeCl}_{2} .4 \mathrm{H}_{2} \mathrm{O}(0.25 \mathrm{~g}, 1.26 \mathrm{mmol}), \mathrm{L}_{1} \mathrm{H}_{2}(0.235 \mathrm{~g}, 1.26 \mathrm{mmol})$, Sodium 9-Anthracene carboxylate $(0.307 \mathrm{~g}, 1.26 \mathrm{mmol})$ and $\mathrm{NaOH}(0.05 \mathrm{~g}, 1.25 \mathrm{mmol})$ were stirred in EtOH (30 $\mathrm{cm}^{3}$ ) for $2 \mathrm{~h}$, filtered and allowed to evaporate to dryness. The resultant solid was then dissolved in a 1:1 $\mathrm{MeCN}: \mathrm{CH}_{2} \mathrm{Cl}_{2}$ solvent mixture, filtered and left to stand. Dark red crystals of 2 were formed upon slow evaporation in 15\% yield after 5 days. Elemental analysis (\%) calculated (found) for $\mathrm{C}_{188} \mathrm{H}_{132} \mathrm{~N}_{10} \mathrm{O}_{28} \mathrm{Fe}_{6}$ : C 68.13 (68.37), $\mathrm{H} 4.01$ (3.84); N 4.23 (4.11). FTIR $\left(\mathrm{cm}^{-1}\right)$ : 2982(vb), 1616(w), 1555(s), 1529(m), 1487 (w), 1425(s), 1391(s), 1317(s), 1279(m), 1248(w), 1187(w),1143(w), 1092(w), 1034(w), 1014(m), 954(m), 884(w), 866.2(w), 846(w), 825(w), 782(w), 729(s), 679(m), 662(m).

\subsubsection{Synthesis of $\left[\mathrm{Fe}(\mathrm{III})_{4}\left(\mathrm{~L}_{2}\right)_{4}(\mathrm{MeOH})_{4}(\mathrm{Cl})_{4}\right](3)$.}

To a stirring solution of $\mathrm{FeCl}_{2} \cdot 4 \mathrm{H}_{2} \mathrm{O}(0.25 \mathrm{~g}, 1.26 \mathrm{mmol})$ in $\mathrm{MeOH}\left(25 \mathrm{~cm}^{3}\right)$ was added 3,5di-tert-butyl-salicylaldoxime $(0.313 \mathrm{~g}, 1.26 \mathrm{mmol})$ and $\mathrm{NaOH}(0.05 \mathrm{~g}, 1.26 \mathrm{mmol})$. The solution was stirred for $2 \mathrm{~h}$ after which time it was filtered to afford a purple-black mother liquor. Slow evaporation of the solvent afforded X-ray quality crystals of $\mathbf{3}$ in $45 \%$ yield. Elemental Analysis calculated (found) for $3\left(\mathrm{C}_{64} \mathrm{H}_{100} \mathrm{~N}_{4} \mathrm{Cl}_{4} \mathrm{Fe}_{4} \mathrm{O}_{12}\right)$ : C 51.87 (51.42); H 6.80 (6.54); N 3.78 (3.30). FT-IR ( $\left.\mathrm{cm}^{-1}\right)$ : 3243(w), 2956(m), 2905(w), 2869(w), 1602(w), 1586(m), 1548(w), 1534(w), 1478(w), 1460(w), 1423(m), 1387(w), 1363(m), 1296(m), 1273(m), 1253(s), 1232(w), 1201(m), 1174(m), 1136(w), 1118(w), 1005(m), 973(s), 954(s), 930(w), 902(w), 874(w), 842(s), 817(w), 775(m), 749(m), 711(s).

\section{Results and Discussion}

The reaction of $\mathrm{FeCl}_{2} \cdot 4 \mathrm{H}_{2} \mathrm{O}, \mathrm{L}_{1} \mathrm{H}_{2}$, Sodium 1-Naphthoate and $\mathrm{NaOMe}$ in $\mathrm{MeOH}$ resulted in the formation of a black solid after evaporation of the mother liquor. Subsequent dissolution of this solid in a 50:50 MeCN: $\mathrm{CH}_{2} \mathrm{Cl}_{2}$ solvent mixture, followed by filtration and slow evaporation of the mother liquor afforded dark red crystals of $\left[\mathrm{Fe}(\mathrm{III})_{6} \mathrm{O}_{2}\left(\mathrm{~L}_{1}\right)_{2}\left(\mathrm{O}_{2} \mathrm{C}\right.\right.$ $\left.\left.\mathrm{C}_{10} \mathrm{H}_{8}\right)_{10}\left(\mathrm{H}_{2} \mathrm{O}\right)_{2}\right] \cdot 8 \mathrm{MeCN}$ (1) in $20 \%$ yield. As anticipated, employing Sodium 9Anthracenecarboxylate gave rise to the analogous hexanuclear complex $\left[\mathrm{Fe}(\mathrm{III})_{6} \mathrm{O}_{2}\left(\mathrm{~L}_{1}\right)_{2}\left(\mathrm{O}_{2} \mathrm{C}-\mathrm{C}_{14} \mathrm{H}_{10}\right)_{10}\left(\mathrm{H}_{2} \mathrm{O}\right)_{2}\right] \cdot 8 \mathrm{MeCN}$ (2) in $15 \%$ yield. Complexes 1 and 2 both 
crystallise in the triclinic $P-1$ space group. Their inorganic cores consist of two fused $\left[\mathrm{Fe}(\mathrm{III})_{3}\left(\mu_{3}-\mathrm{O}\right)\left(\mathrm{O}_{2}-\mathrm{CR}\right)_{5}\right]$ triangular units (where $\mathrm{R}=\mathrm{C}_{10} \mathrm{H}_{8}$ in $\mathbf{1} ; \mathrm{R}=\mathrm{C}_{14} \mathrm{H}_{10}$ in 2), lying offset to one another (Fig. 1 and S1). Complexes 1 and 2 join a small group of previously reported oxime-based hexametallic cages which include $\left[\mathrm{Fe}_{6} \mathrm{O}_{2}\left(\mathrm{O}_{2} \mathrm{CPh}\right)_{10}(\mathrm{salox})_{2}\right](\mathrm{salox}=$ salicyaldoxime $)[9 \mathrm{a}]$ and $\left[\mathrm{Fe}_{6} \mathrm{O}_{2}\left(\mathrm{O}_{2} \mathrm{CPh}\right)_{10}(\mathrm{R}-\mathrm{sao})_{2}\right]\left(\mathrm{R}-\mathrm{saoH}_{2}=3-{ }^{t} \mathrm{Bu}-5-\mathrm{NO}_{2}\right.$-salicyaldoxime and $3{ }^{t} \mathrm{Bu}$-salicyaldoxime) [9b]. They also have structural similarity to another family of hexanuclear cages of general formula $\left[\mathrm{Fe}_{6} \mathrm{O}_{2}(\mathrm{OH})_{2}\left(\mathrm{O}_{2} \mathrm{C}-\mathrm{R}\right)_{10}(\mathrm{~L})_{2}\right]\left(\mathrm{R}={ }^{t} \mathrm{Bu}, \mathrm{L}=2-(2-\right.$ hydroxyethyl)-pyridine [15]; and $\mathrm{R}={ }^{t} \mathrm{Bu}$ or $\mathrm{Me}, \mathrm{L}=2$-(2-hydroxyethyl)-pyridine or 6methyl-2-(hydroxymethyl)pyridine [16]), whose inorganic cores differ only in the presence of two $\mu_{2}$-bridging $\mathrm{OH}^{-}$anions [17].

Each $\mathrm{Fe}(\mathrm{III})$ centre exhibits a distorted octahedral geometry. The triangular units in $\mathbf{1}$ and $\mathbf{2}$ closely resemble the classic, ubiquitous oxo-bridged trimeric species of general formula $\left[\mathrm{M}_{3}\left(\mu_{3}-\mathrm{O}\right)\left(\mathrm{O}_{2}-\mathrm{CR}\right)_{6}(\mathrm{~L})_{3}\right]^{\mathrm{n}+}(\mathrm{n}=0,1)[18]$, differing only in the replacement of one carboxylate bridging ligand with one $\mathrm{L}^{2-}$ ligand per $\left.\left\{\mathrm{Fe}_{3}\left(\mu_{3}-\mathrm{O}\right)\left(\mathrm{O}_{2}-\mathrm{CR}\right)_{5}\right)\right\}^{2+}$ unit. Indeed these $\eta^{1}: \eta^{1}: \eta^{2}: \mu_{3}$-bridging oxime ligands are responsible for joining the trimeric units together via their oximic $\mathrm{O}$ atoms $\left(\mathrm{O} 2\right.$ in 1 and $\mathrm{O} 3$ in 2) with angles of $\mathrm{Fe} 3-\mathrm{O} 2-\mathrm{Fe} 3^{\prime}=$ $104.48^{\circ}$ and $\mathrm{Fe} 3-\mathrm{O} 3-\mathrm{Fe} 3^{\prime}=106.49^{\circ}$, respectively. Moreover, each of these doubly deprotonated oxime ligands $\left(\mathrm{L}^{2-}\right)$ are able to bridge one $\mathrm{Fe}{ }^{\cdots} \mathrm{Fe}$ edge of each $\left\{\mathrm{Fe}_{3}\left(\mu_{3}-\mathrm{O}\right)\right\}$ unit $(\mathrm{Fe} 1 \cdots \mathrm{Fe} 3$ in $\mathbf{1}$ and $\mathrm{Fe} 2 \cdots \mathrm{Fe} 3$ in 2$)$ to form $\mathrm{Fe}-\mathrm{N}-\mathrm{O}-\mathrm{Fe}$ pathways (Fig. 1). The coordination spheres at $\mathrm{Fe} 2$ in $\mathbf{1}$ and $\mathrm{Fe} 1$ in $\mathbf{2}$ (and symmetry equivalents) are completed by terminal $\mathrm{H}_{2} \mathrm{O}$ ligands $(\mathrm{Fe} 2-\mathrm{O} 14=2.118 \AA$, Fe1-O14 = $2.103 \AA$ ). Eight MeCN solvents of crystallisation per $\mathrm{Fe}_{6}$ cage are also present in both crystal structures, $\mathrm{H}$-bonding via their $\mathrm{N}$ atoms to nearby carboxylate and $\mathrm{H}_{2} \mathrm{O}$ ligands $($ e.g. $\mathrm{C} 43(\mathrm{H} 43) \cdots \mathrm{N} 5=2.690 \AA$ and $\mathrm{O} 14 \cdots \mathrm{N} 2=2.812 \AA$ in $\mathbf{1}$; $\mathrm{C} 50(\mathrm{H} 50) \cdots \mathrm{N} 2=2.671 \AA$ and $\mathrm{O} 14 \cdots \mathrm{N} 2=2.834 \AA$ in 2$)$. Both complexes 1 and 2 exhibit intra-molecular $\pi-\pi$ interactions via their naphthoate and anthracenoate rings, in the form of $\pi-\pi$ contacts $\left(e . g . \quad\left[\mathrm{C}_{46}-\mathrm{C}_{55}\right]_{\text {centroid }}{ }^{\cdots}\left[\mathrm{C}_{35}-\mathrm{C}_{40}\right]_{\text {centroid }}=4.042 \AA(\mathbf{1})\right.$ and $\left[\mathrm{C}_{13}-\mathrm{C}_{26}\right] \cdots\left[\mathrm{C}_{58}-\mathrm{C}_{71}\right]=$ $3.988 \AA$ (2)) (Fig. S2).

The individual $\left\{\mathrm{Fe}_{6}\right\}$ units in $\mathbf{1}$ arrange in superimposable 1-D rows along the $b$ cell direction (Fig. 2). These rows stack on top and by the side of one another (along the $a c$ plane) in an interdigitated fashion, propagated through $\mathrm{C}-\mathrm{H}^{\cdots} \pi$ interactions between $\left\{\mathrm{Fe}_{6}\right\}$ moieties $($ e.g. $\mathrm{C}_{9}\left(\mathrm{H}_{9}\right) \cdots\left[\mathrm{C}_{14}-\mathrm{C}_{19}\right]=2.934 \AA$ ) (Fig. 3). The MeCN molecules of crystallisation lie in between the cages in 1, stabilising this packing arrangement through the aforementioned intermolecular interactions. 
The individual $\left\{\mathrm{Fe}_{6}\right\}$ units in $\mathbf{2}$ arrange themselves into superimposable rows along the $c$ cell direction and are linked via symmetry related inter-molecular $\pi$ - $\pi$ interactions $\left(\left[\mathrm{C}_{29}-\mathrm{C}_{34}\right]\right.$ centroid ${ }^{\prime \prime}\left[\mathrm{C}_{29^{\prime}}-\mathrm{C}_{34^{\prime}}\right]_{\text {centroid }}=3.842 \AA$ ) (Fig. 2). These rows then stack in off-set parallel rows in both the $a$ and $b$ cell directions. MeCN molecules of crystallisation lie in between the 1-D rows and are held by hydrogen bonding, as described previously in $\mathbf{1}$.
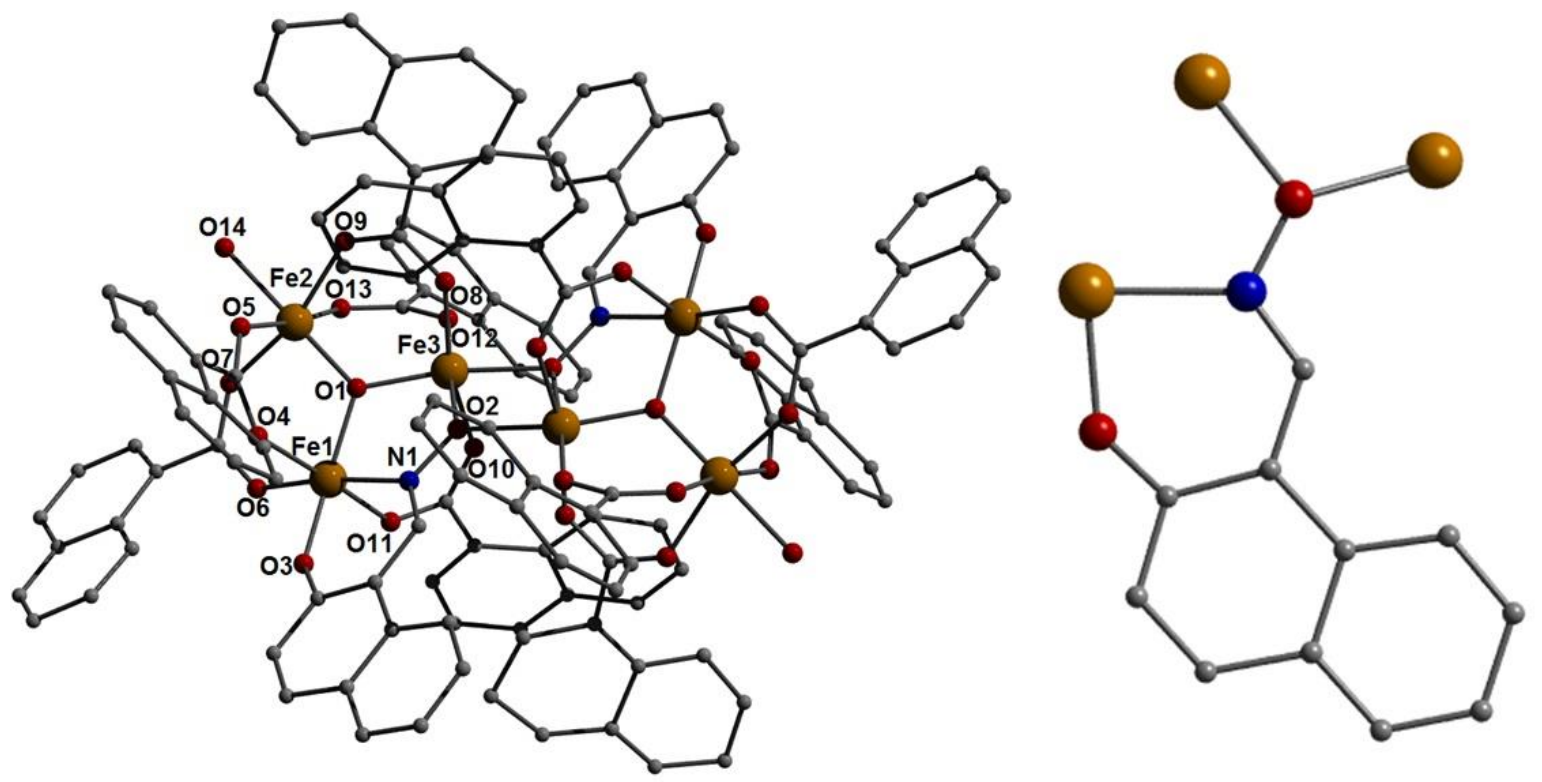

Figure 1 (left) Crystal structure of 1 as viewed perpendicular to the $\left\{\mathrm{Fe}_{6}\right\}$ plane. (right) The $\eta^{1}: \eta^{1}: \eta^{2}: \mu_{3}$-bonding mode demonstrated by the oxime ligands in $\mathbf{1}$ and $\mathbf{2}$. Colour code: Orange $(\mathrm{Fe}), \operatorname{Red}(\mathrm{O})$, Blue (N), Grey (C). Hydrogen atoms omitted for clarity.
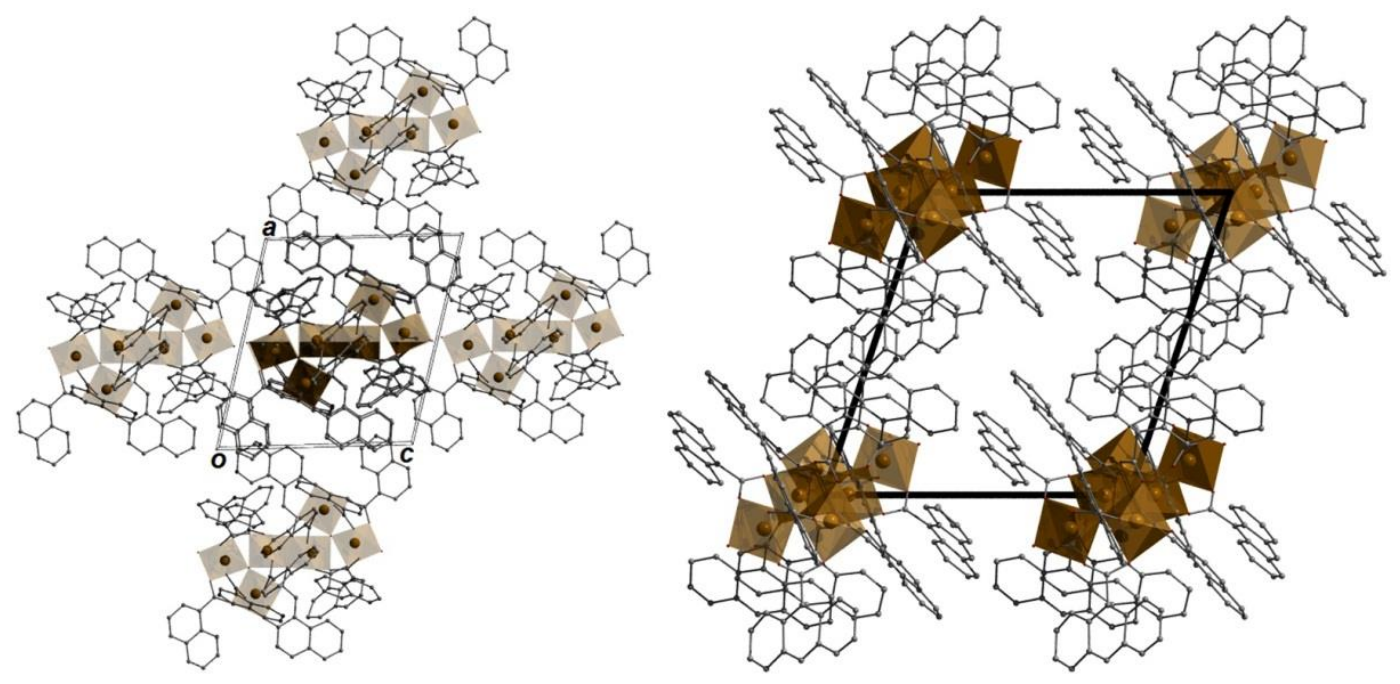
Figure 2 Polyhedral representation of the packing observed in the crystal structures of $\mathbf{1}$ (left) and $\mathbf{2}$ (right) as viewed along the $b$ and $c$ axes of their unit cells, respectively. Hydrogen atoms and $\mathrm{MeCN}$ molecules of crystallisation have been omitted for clarity in both cases.

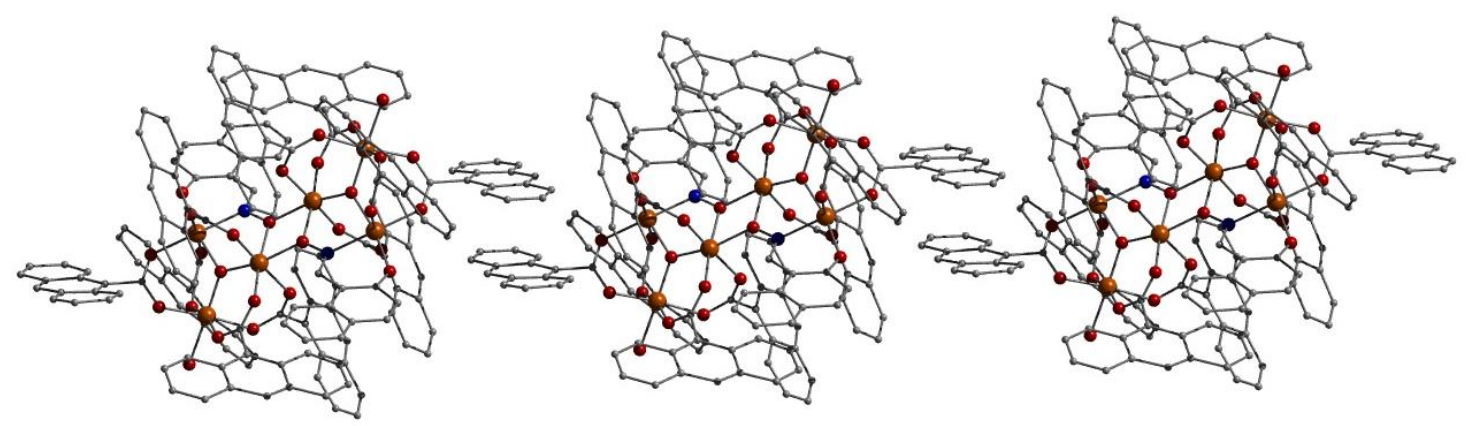

Figure 31 -D row of $\left\{\mathrm{Fe}_{6}\right\}$ units in 2 propagated by inter-molecular $\pi-\pi$ interactions along the $c$ cell direction. Hydrogen atoms have been omitted for clarity. See main text for details.

Reactions of the rarely employed 3,5-di-tert-butyl-salicylaldoxime $\left(\mathrm{L}_{2} \mathrm{H}_{2}\right.$; Scheme 1) in combination with bulky carboxylates proved fruitless, but omission of the co-ligand resulted in formation of $\left[\mathrm{Fe}(\mathrm{III})_{4}\left(\mathrm{~L}_{2}\right)_{4}(\mathrm{MeOH})_{4}(\mathrm{Cl})_{4}\right]$ (3) via the simple reaction of $\mathrm{FeCl}_{3} \cdot 4 \mathrm{H}_{2} \mathrm{O}$ and $\mathrm{L}_{2} \mathrm{H}_{2}$ in a basic methanolic solution (Fig. 4). Dark red crystals of (3) were obtained in $45 \%$ yield and crystallised in the monoclinic space group $C 2 / c(Z=4)$. The inorganic core in 3 comprises four $\mathrm{Fe}(\mathrm{III})$ ions ( $\mathrm{Fe} 1, \mathrm{Fe} 2$ and symmetry equivalents) linked into a distorted tetrahedral arrangement via four doubly deprotonated $\mathrm{L}_{2}{ }^{2-}$ ligands, each employing an $\eta^{1}: \eta^{1}: \eta^{2}: \mu_{3}$-bonding motif (Fig. 4). The result is the formation of a severely distorted $\left\{\mathrm{Fe}(\mathrm{III})_{4}(\mathrm{NO})_{4}\right\}^{4+}$ cube, a topology observed only once previously in Fe-oxime chemistry [7]. Each Fe(III) ion exhibits a distorted octahedral geometry, with their coordination spheres completed by one $\mathrm{Cl}^{-}$ion $(\mathrm{Fe} 1-\mathrm{Cl} 2=2.313 \AA$ $; \mathrm{Fe} 2-\mathrm{Cl} 1=2.301 \AA)$ and one terminal $\mathrm{MeOH}$ ligand $\left(\mathrm{Fe} 1-\mathrm{O} 5 \mathrm{~A}=2.097 \AA\right.$; Fe2-O6A = $2.093 \AA$ ). The intra-molecular $\mathrm{Fe} 1{ }^{\cdots} \mathrm{Fe} 1{ }^{\prime}, \mathrm{Fe} 1{ }^{\cdots} \mathrm{Fe} 2$ and $\mathrm{Fe} 2 \cdots \mathrm{Fe} 2$ ' distances are $(\AA): 4.043,3.581$ and 4.152. Interestingly, and despite huge efforts, no other ferric cages were obtained with or without the inclusion of co-ligands during our synthetic investigations with 3,5-di-tert-butyl-salicylaldoxime $\left(\mathrm{L}_{2} \mathrm{H}_{2}\right)$. This may tentatively be attributed to the steric nature of the 3,5-di-tert-butyl-salicylaldoxime ligand. 


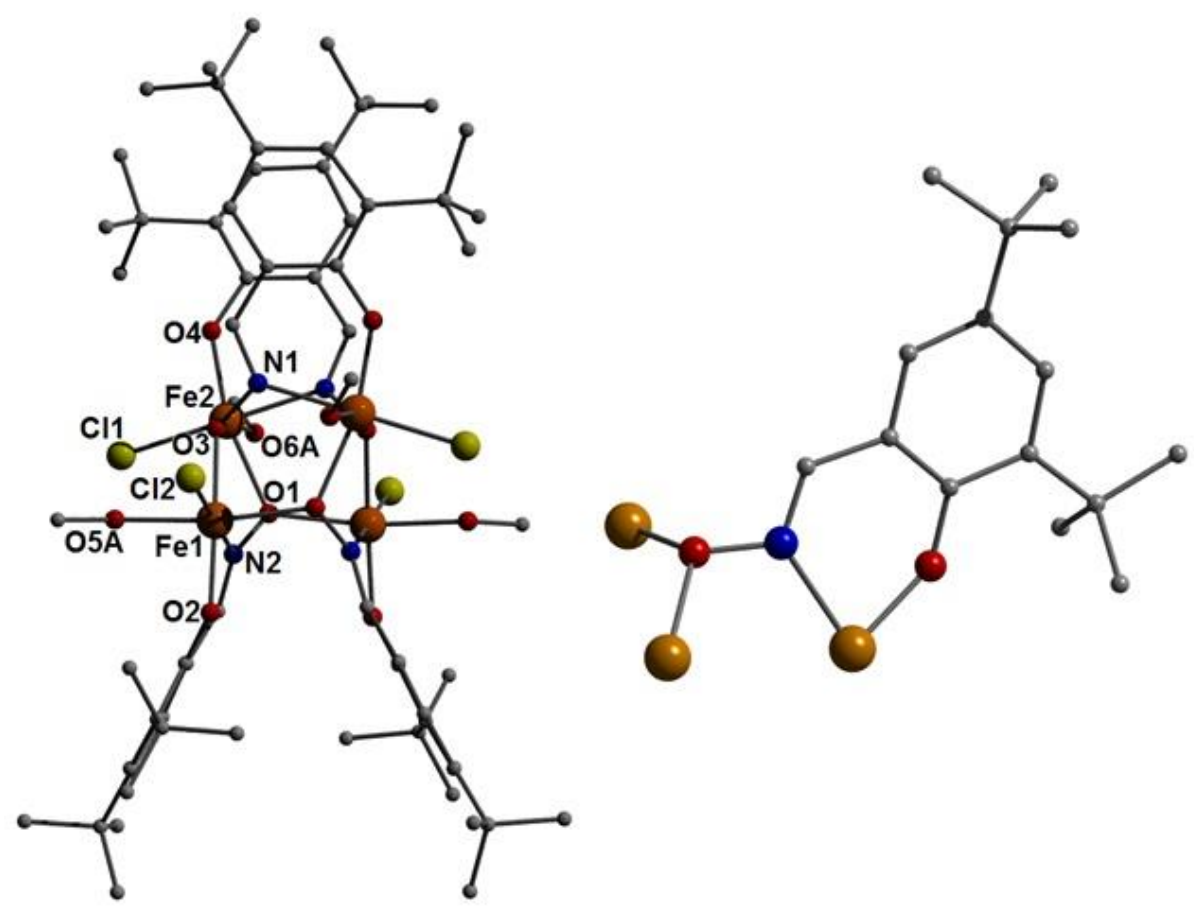

Figure 4 (left) Crystal structure of 3. (right) The $\eta^{1}: \eta^{1}: \eta^{2}: \mu_{3}$-bonding mode demonstrated by the 3,5-di-tert-butyl salicyaldoxime $\left(\mathrm{L}_{2}^{-}\right)$ligands in $\mathbf{3}$. Colour code as used previously in the text $($ yellow $=\mathrm{Cl})$. Hydrogen atoms have been omitted for clarity.

Intra-molecular interactions are observed in $\mathbf{3}$ in the form of rather long $\pi-\pi$ interactions $\left(\left[\mathrm{C}_{2}-\right.\right.$ $\left.\mathrm{C}_{7}\right]_{\text {centroid }}{ }^{\cdots}\left[\mathrm{C}_{2^{\prime}}-\mathrm{C}_{7^{\prime}}\right]_{\text {centroid }}=4.587 \AA$ ) and hydrogen bonding between the terminal $\mathrm{Cl}^{-}$ligands (Cl1) and juxtaposed terminal $\mathrm{MeOH}$ ligands $(\mathrm{Cl1} \cdots \mathrm{H} 5 \mathrm{~A}(\mathrm{O} 5 \mathrm{~A})=2.266 \AA)$. The $\left\{\mathrm{Fe}_{4}\right\}$ units in 3 pack in a brickwork motif along the $a b$ cell plane. These $2 \mathrm{D}$ sheets then stack in an offset parallel arrangement along the $c$ direction of the unit cell (Fig. 5). The individual $\left\{\mathrm{Fe}_{4}\right\}$ moieties are connected through a combination of inter-molecular $\mathrm{C}-\mathrm{H} \cdots \pi$ exchanges (i.e. $\mathrm{C} 31(\mathrm{H} 31 \mathrm{~B}) \ldots\left[\mathrm{C}_{17}-\mathrm{C}_{22}\right]_{\text {centroid }}=2.888 \AA$ and $\left.\mathrm{C} 32(\mathrm{H} 32 \mathrm{~B}) \cdots\left[\mathrm{C}_{2}-\mathrm{C}_{7}\right]_{\text {centroid }}=3.174 \AA\right)$ and $\mathrm{H}-$ bonding interactions between the terminal $\mathrm{Cl}^{-}$ions $(\mathrm{Cl1})$ and methyl protons belonging to tert-butyl groups of adjacent $\mathrm{L}_{2}^{2-}$ ligands $(\mathrm{Cl} 1 \cdots \mathrm{H} 29(\mathrm{C} 29)=2.911 \AA$ ). 


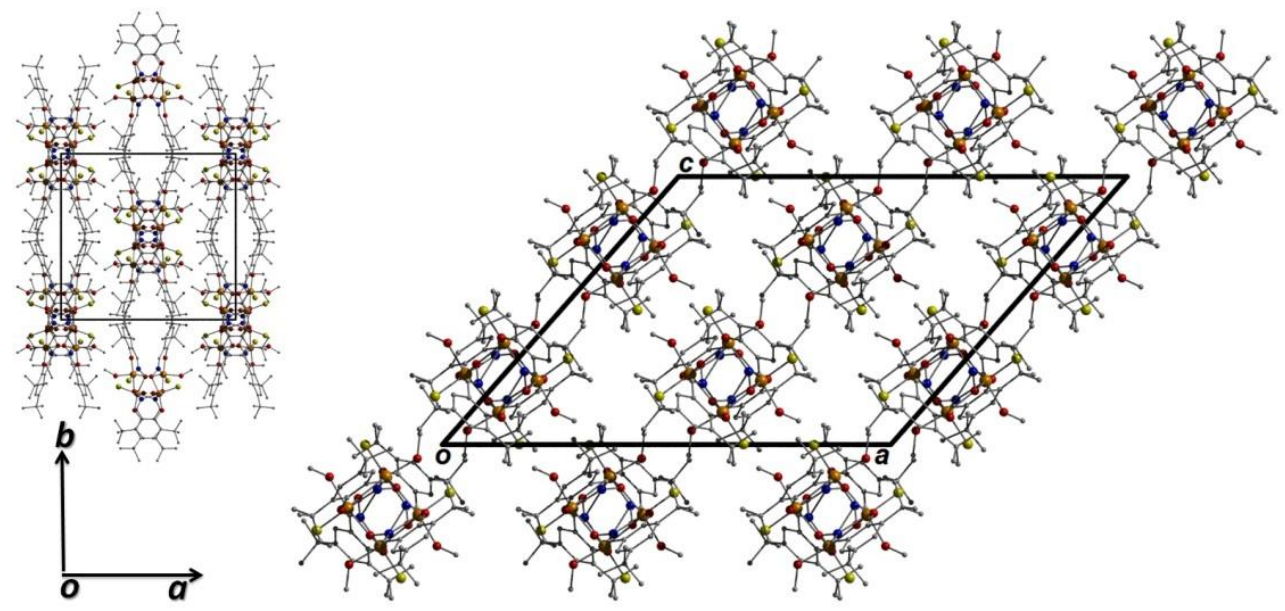

Figure 5 Packing observed in the crystal structure of $\mathbf{3}$ as viewed along the $c$ (left) and $b$ (right) axes of the unit cell. Hydrogen atoms have been omitted for clarity. Colour code as used previously in the text.

Table 1 Single crystal X-ray diffraction data collected on complexes 1-3

\begin{tabular}{|c|c|c|c|}
\hline & 1 & 2 & 3 \\
\hline Formula $^{\mathrm{a}}$ & $\mathrm{C}_{148} \mathrm{H}_{108} \mathrm{~N}_{10} \mathrm{O}_{28} \mathrm{Fe}_{6}$ & $\mathrm{C}_{188} \mathrm{H}_{128} \mathrm{~N}_{10} \mathrm{O}_{28} \mathrm{Fe}_{6}$ & $\mathrm{C}_{64} \mathrm{H}_{100} \mathrm{~N}_{4} \mathrm{O}_{12} \mathrm{Cl}_{4} \mathrm{Fe}_{4}$ \\
\hline$M_{\mathrm{W}}$ & 2809.54 & 3310.1 & 1482.68 \\
\hline Crystal System & Triclinic & Triclinic & Monoclinic \\
\hline Space group & $\mathrm{P}-1$ & $\mathrm{P}-1$ & $\mathrm{C} 2 / \mathrm{c}$ \\
\hline$a / \AA$ & $14.0705(10)$ & $16.5927(17)$ & $25.946(3)$ \\
\hline$b / \AA ̊ \AA$ & $15.8707(12)$ & $17.0191(15)$ & $18.4694(9)$ \\
\hline$c / \AA$ & $16.3405(12)$ & $17.936(2)$ & $20.669(2)$ \\
\hline$\alpha /^{\circ}$ & $108.865(7)$ & $67.615(10)$ & 90 \\
\hline$\beta /^{\circ}$ & $102.576(6)$ & $64.944(11)$ & 131.402(19) \\
\hline$\gamma /^{\circ}$ & $94.211(6)$ & $64.707(9)$ & 90 \\
\hline$V / \AA^{3}$ & $3329.0(4)$ & 4023.1(7) & $7429.5(12)$ \\
\hline$Z$ & 1 & 1 & 4 \\
\hline$T / \mathrm{K}$ & $150(2)$ & $150(2)$ & $150(2)$ \\
\hline$\lambda^{\mathrm{b} / \AA} \AA$ & 0.7107 & 0.7107 & 0.7107 \\
\hline $\begin{array}{c}D_{\mathrm{c}} / \mathrm{g} \mathrm{cm}^{-3} \\
\mu(\mathrm{Mo}-\mathrm{Ka}) / \mathrm{mm}^{-1}\end{array}$ & $\begin{array}{l}1.401 \\
0.715\end{array}$ & $\begin{array}{l}1.366 \\
0.604\end{array}$ & $\begin{array}{l}1.326 \\
0.966\end{array}$ \\
\hline Meas./indep. $\left(R_{\text {int }}\right)$ refl. & $12186 / 4955(0.112)$ & 14712 / $3444(0.203)$ & 6792 / $4247(0.070)$ \\
\hline wR2 (all data) & 0.2563 & 0.4281 & 0.1575 \\
\hline \multirow{2}{*}{$\begin{array}{c}R 1^{d, e} \\
\text { Goodness of fit on } F^{2}\end{array}$} & 0.0936 & 0.1285 & 0.0587 \\
\hline & 0.985 & 0.944 & 1.036 \\
\hline
\end{tabular}


Table 2 Equivalent Spin Hamiltonian parameters obtained from $\mathbf{3}$ and its previously reported analogue.

\begin{tabular}{c|c|c|c|c|c} 
Complex & $\mathbf{J}_{\mathbf{1}}\left(\mathbf{c m}^{-\mathbf{1}}\right)$ & $\mathbf{J}_{\mathbf{2}}\left(\mathbf{c m}^{-\mathbf{1}}\right)$ & $\mathbf{g}$ & Ground Spin State $(\mathbf{S})$ & Ref \\
\hline $\mathbf{3}$ & -16.0 & -2.0 & 2.00 & 0 & This work \\
{$\left[\mathrm{Fe}_{4}(\mathrm{Me}-\mathrm{sao})_{4}(\mathrm{Me}-\mathrm{saoH})_{4}\right]^{*}$} & -12.4 & -5.5 & 2.01 & 0 & 7 \\
\hline
\end{tabular}

(* Me-saoH ${ }_{2}=2^{\prime}$-hydroxyacetophenone oxime)

Infra-red spectroscopic studies were carried out on air dried crystalline samples of 1-3. Weak IR bands were observed in the $1555-1597 \mathrm{~cm}^{-1}$ region of the spectra and are attributed to multiple aromatic $v(C=C)$ stretching vibrations [19]. The multiple bands centred on the 1578$1616 \mathrm{~cm}^{-1}$ region of the spectra comprise indistinguishable $v(\mathrm{CO})$ carboxylate and $v(\mathrm{C}=\mathrm{N})$ oxime stretching modes, as observed elsewhere [20]. Attempts at assigning the $v(\mathrm{~N}-\mathrm{O})$ oxime stretching modes in 1-3 were severely hampered by the significant spectral overlap in the $900-1150 \mathrm{~cm}^{-1}$ region of the IR spectra. Previous reports on ligating aromatic oximes have documented $v(\mathrm{~N}-\mathrm{O})$ stretching IR bands in the $\sim 1050-1250 \mathrm{~cm}^{-1}$ spectral range and so should be considered here [21]. Quenching due to Fe(III) ligation in complexes $\mathbf{1}$ and $\mathbf{2}$ rendered all solid state fluorescence studies fruitless.

\subsection{Magnetic susceptibility studies}

Magnetic susceptibility $\left(\chi_{\mathrm{M}}\right)$ measurements were carried out on powdered polycrystalline samples of 1 and $\mathbf{3}$ in the 300-5 K temperature range, in an applied dc field of 0.1 T (Fig. 7). The room temperature $\chi_{\mathrm{MT}} \mathrm{T}$ values of $6.38(\mathbf{1})$ and $9.54(3) \mathrm{cm}^{3} \mathrm{~mol}^{-1} \mathrm{~K}$ are significantly lower than expected for six and four non interacting Fe(III) ions (26.25 (1) and $17.5(3) \mathrm{cm}^{3}$ $\mathrm{mol}^{-1} \mathrm{~K}$, assuming $\mathrm{g}=2.0$ ), respectively. Such observations are indicative of dominant antiferromagnetic interactions between the Fe(III) ions in both complexes. For 1 the $\chi_{M} T$ product decreases gradually with decreasing temperature, before a steeper decline is witnessed below approximately $50 \mathrm{~K}$, reaching a minimum value of $1.46 \mathrm{~cm}^{3} \mathrm{~mol}^{-1} \mathrm{~K}$ at $5 \mathrm{~K}$. Fitting of the experimental data for (1) required use of the $3-\mathrm{J}$ model ( $\mathrm{J}_{1}$ mediated by carboxylate and oxide; $\mathrm{J}_{2}$ by carboxylate, oxide and oxime; and $\mathrm{J}_{3}$ by alkoxide) described in Figure 6 and equation (1), affording the best-fit parameters $J_{1}=-69.35 \mathrm{~cm}^{-1}, J_{2}=-41.66 \mathrm{~cm}^{-1}$ and $\mathrm{J}_{3}=-0.32 \mathrm{~cm}^{-1}$, with $\mathrm{g}$ fixed to $\mathrm{g}=2.00$, resulting in a $\mathrm{S}=0$ ground state. Such values are consistent with those obtained from previously reported analogues [9a]. 
Eqn. (1): $\hat{H}=2 J_{1}\left(\hat{S}_{1} \cdot \hat{S}_{2}+\hat{S}_{2} \cdot \hat{S}_{3}+\hat{S}_{1^{\prime}} \cdot \hat{S}_{2^{\prime}}+\hat{S}_{2^{\prime}} \cdot \hat{S}_{3^{\prime}}\right)-2 J_{2}\left(\hat{S}_{1} \cdot \hat{S}_{3}+\hat{S}_{1^{\prime}} \cdot \hat{S}_{3^{\prime}}\right)-2 J_{3}\left(\hat{S}_{1^{\prime}} \cdot \hat{S}_{3^{\prime}}+\right.$

$$
\left.\hat{S}_{1^{\prime}} \cdot \hat{S}_{3}+\hat{S}_{3} \cdot \hat{S}_{3^{\prime}}\right)
$$

Eqn. (2): $\hat{H}=2 J_{1}\left(\hat{S}_{1} \cdot \hat{S}_{1^{\prime}}+\hat{S}_{2} \cdot \hat{S}_{2^{\prime}}\right)-2 J_{2}\left(\hat{S}_{1} \cdot \hat{S}_{2}+\hat{S}_{1} \cdot \hat{S}_{2^{\prime}}+\hat{S}_{1^{\prime}} \cdot \hat{S}_{2}+\hat{S}_{1^{\prime}} \cdot \hat{S}_{2^{\prime}}\right)$
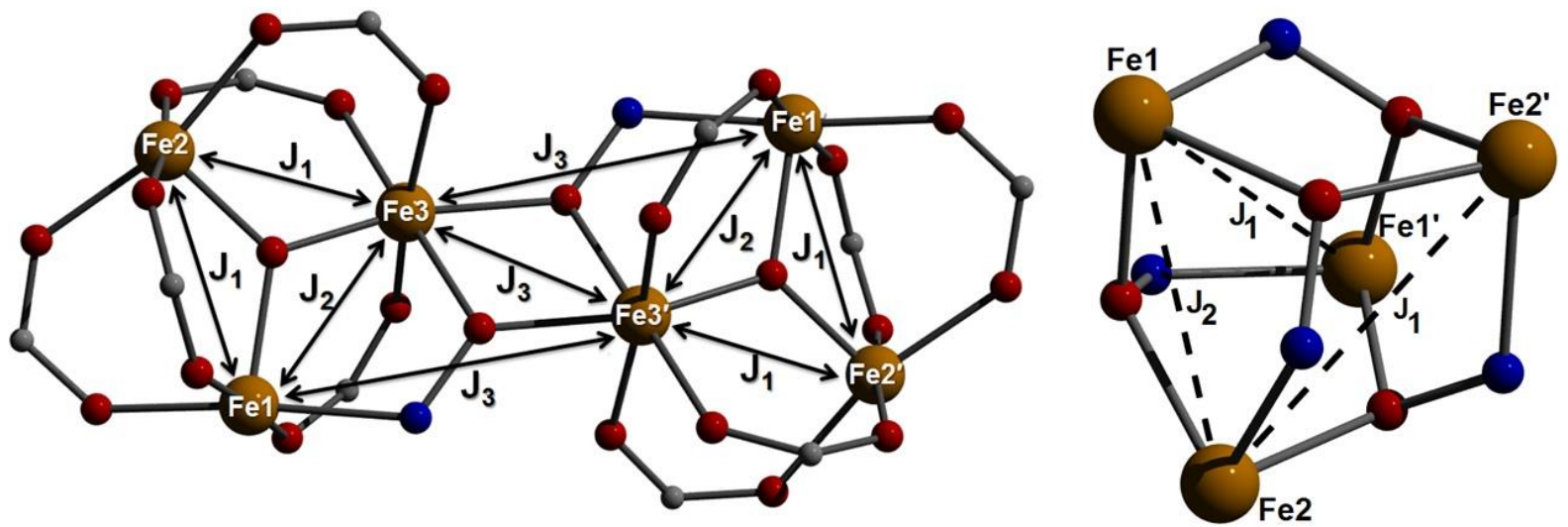

Figure 6 Schematic of the models used to fit the magnetic susceptibility data of complex 1 (left) and complex 2 (right). Note: for clarity not all magnetic exchange pathways have been labelled. See main text for details.

The $\chi_{\mathrm{M}} \mathrm{T}$ vs. T plot for complex $\mathbf{3}$ is also indicative of dominant antiferromagnetic exchange and a diamagnetic ground state (Fig. 7). Fitting of the magnetic susceptibility data employed the $2 \mathrm{~J}$ model of equation 2, illustrated in Fig. 6, in which $\mathrm{J}_{1}$ represents the $\mathrm{Fe} 1^{\cdots} \mathrm{Fe} 1^{\prime}$ and $\mathrm{Fe} 2 \cdots \mathrm{Fe} 2^{\prime}$ vectors comprising $2 \times \mathrm{Fe}-\mathrm{N}-\mathrm{O}-\mathrm{Fe}$ oxime bridging pathways, and $\mathrm{J}_{2}$ represents the $\mathrm{Fe} 1{ }^{\cdots} \mathrm{Fe} 2, \mathrm{Fe}^{\prime \cdots}{ }^{\prime \cdots} \mathrm{Fe} 2{ }^{\prime}, \mathrm{Fe} 1{ }^{\cdots}{ }^{\mathrm{Fe}} 22^{\prime}$ and $\mathrm{Fe} 1^{\prime \cdots} \mathrm{Fe} 2$ vectors comprising $1 \times \mathrm{Fe}-\mathrm{N}-\mathrm{O}-\mathrm{Fe}$ and $1 \times \mathrm{Fe}-$ $\mathrm{O}-\mathrm{Fe}$ magnetic exchange pathway (Fig. 6). The best fit afforded $\mathrm{J}_{1}=-16.0 \mathrm{~cm}^{-1}$ and $\mathrm{J}_{2}=-2.0$ $\mathrm{cm}^{-1}$, with $\mathrm{g}$ fixed to $\mathrm{g}=2.00$, which are comparable to the parameters fitted from the structurally similar $\left[\mathrm{Fe}_{4}(\mathrm{Me}-\mathrm{sao})_{4}(\mathrm{Me}-\mathrm{saoH})_{4}\right]$ (where Me-saoH ${ }_{2}=2^{\prime}$-hydroxyacetophenone oxime) (Table 2) [7]. 


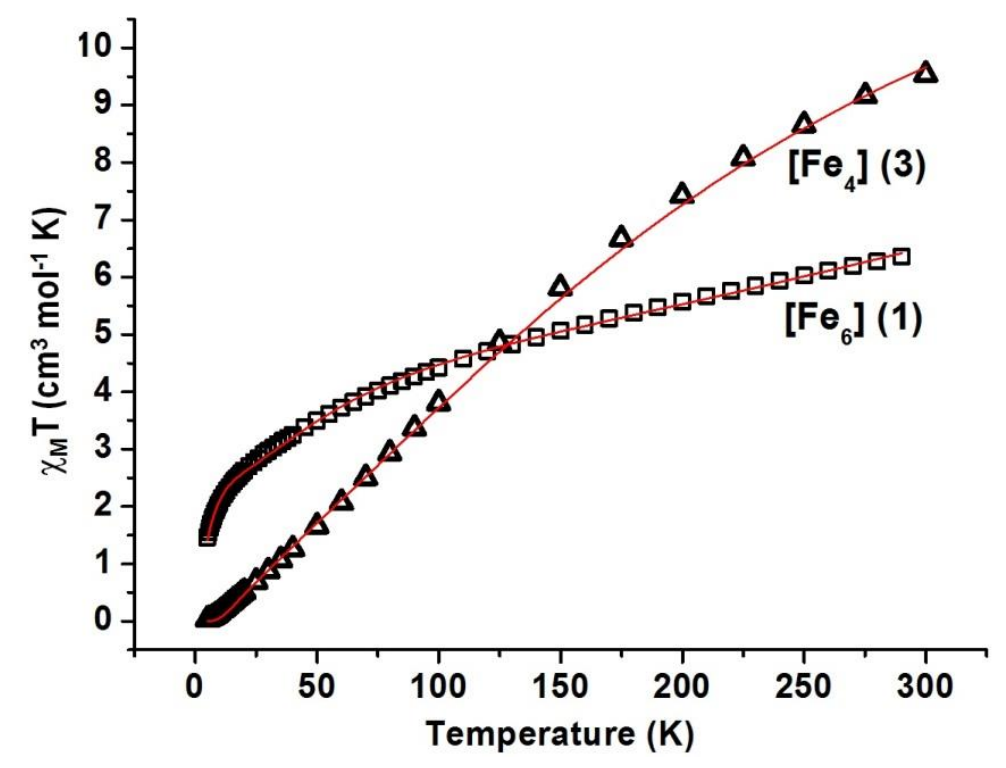

Figure 7 Plot of $\chi_{M} T$ vs $T$ for complexes $1(\square)$ and $\mathbf{3}(\Delta)$. The red lines represent the best-fit of the experimental data. See main text for details.

\section{Concluding Remarks}

We have described the synthesis of two hexanuclear ferric cages $\left[\mathrm{Fe}(\mathrm{III})_{6} \mathrm{O}_{2}\left(\mathrm{~L}_{1}\right)_{2}\left(\mathrm{O}_{2} \mathrm{C}\right.\right.$ $\left.\left.\mathrm{C}_{10} \mathrm{H}_{8}\right)_{10}\left(\mathrm{H}_{2} \mathrm{O}\right)_{2}\right] \cdot 8 \mathrm{MeCN}$ (1) and $\left[\mathrm{Fe}(\mathrm{III})_{6} \mathrm{O}_{2}\left(\mathrm{~L}_{1}\right)_{2}\left(\mathrm{O}_{2} \mathrm{C}-\mathrm{C}_{14} \mathrm{H}_{10}\right)_{10}\left(\mathrm{H}_{2} \mathrm{O}\right)_{2}\right] \cdot 8 \mathrm{MeCN}$ (2). The core topologies in $\mathbf{1}$ and $\mathbf{2}$ are derived from the fusion of two $\left\{\mathrm{Fe}(\mathrm{III})_{3} \mathrm{O}\left(\mathrm{O}_{2} \mathrm{CR}\right)_{5}\right\}^{2+}$ triangular units $\left(\mathrm{R}=\mathrm{C}_{10} \mathrm{H}_{8} ; \mathrm{C}_{12} \mathrm{H}_{10}\right)$ and are encased by an organic sheath provided by the combination of extremely bulky polyphenolic oxime and carboxylate ligands. The bulky 3,5-di-tertButyl-salicylaldoxime $\left(\mathrm{L}_{2} \mathrm{H}_{2}\right)$ ligand led to the formation of the distorted cubane complex $\left[\mathrm{Fe}(\mathrm{III})_{4}\left(\mathrm{~L}_{2}\right)_{4}(\mathrm{MeOH})_{4}(\mathrm{Cl})_{4}\right](\mathbf{3})$. Magnetic susceptibility data obtained for $\mathbf{1}$ and $\mathbf{3}$ revealed relatively strong antiferromagnetic exchange between nearest neighbours in both cases, leading to diamagnetic ground states. Best fit spin Hamiltonian parameters were $\mathrm{J}_{1}=-69.35$ $\mathrm{cm}^{-1}, \mathrm{~J}_{2}=-41.66 \mathrm{~cm}^{-1}, \mathrm{~J}_{3}=-0.23 \mathrm{~cm}^{-1}(\mathbf{1})$ and $\mathrm{J}_{1}=-16.0 \mathrm{~cm}^{-1}, \mathrm{~J}_{2}=-2.0 \mathrm{~cm}^{-1}(\mathbf{3})$.

\section{Acknowledgements}

LFJ wishes to thank the Irish Research Council for Science and Technology (IRCSET Embark Program (EH)) for their support. EKB thanks the EPSRC.

\section{References}


[1] A. M. Wilson, P. J. Bailey, P. A. Tasker, J. R. Turkington, R. A. Grant and J. B. Love. Chem. Soc. Rev., 43, (2014), 123-134. (b) B. K. Tait, K. E. Mdlalose and I. Taljaard. Hydrometallurgy. 38, (1995), 1-6.

[2] R. S. Forgan, B. D. Roach, P. A. Wood, F. J. White, J. Campbell, D. N. Hendrickson, E. Kamenetsky, F. E. McAllister, S. Parsons, E. Pidcock, P. Richardson, R. M. Swart and P. A. Tasker. Inorg. Chem., 50, (2001), 4515-4522.

[3] For a comprehensive review on the coordination chemistry of phenolic oximes see: A. G. Smith, P. A. Tasker and D. J. White. Coord. Chem. Rev., 241, (2003), 61-85.

[4] For a comprehensive review on the coordination chemistry of pyridyl oximes see: C. J. Milios, T. C. Stamatatos and S. P. Perlepes. Polyhedron. 25, (2006), 134-194.

[5] R. Inglis, C. Milios, L. F. Jones, S. Piligkos, E. K. Brechin. Chem. Commun., (Feature Article), 48, (2011), 181-190.

[6] R. Inglis, L. F. Jones, C. J. Milios, S. Datta, A. Collins, S. Parsons, W. Wernsdorfer, S. Hill, S. P. Perlepes, S. Piligkos, E. K. Brechin. Dalton Trans., (2009), 3403-3412.

[7] I. A. Gass, C. J. Milios, A. Collins, F. J. White, L. Budd, S. Parsons, M. Murrie, S. P. Perlepes and E. K. Brechin. Dalton Trans., (2008), 2043-2053.

[8] K. Mason, I. A. Gass, F. J. White, G. S. Papaefstathiou, E. K. Brechin and P. A. Tasker. Dalton Trans., 40, (2011), 2875-2881.

[9] (a) C. P. Raptopoulou, A. K. Boudalis, Y. Sanakis, V. Psycharis, J. M. Clement-Juan, M. Fardis, G. Diamantopoulos and G. Papavassiliou. Inorg. Chem., 45, (2006), 23172326. (b) K. Mason, I. A. Gass, S. Parsons, A. Collins, F. J. White, A, M. Z. Slavin, E. K. Brechin and P. A. Tasker. Dalton Trans., 39, (2010), 2727-2734

[10] For examples of Fe-salicyaldoxime complexation see: (a) I. A. Gass, C. J. Milios, A. G. Whittaker, F. P. A. Fabiani, S. Parsons, M. Murrie, S. P. Perlepes and E. K. Brechin. Inorg. Chem., 45, (2006), 5281-5283. (b) P. Chaudhuri, E. Rentschler, F. Birkelbach, C. Krebs, E. Bill, T. Weyhermüller and U. Flörke. Eur. J. Inorg. Chem., (2003), 541-555. (c) C. Nazari Verani, E. Bothe, D. Burdinski, T. Weyhermuller, U. Flörke and P. Chaudhuri. Eur. J. Inorg. Chem., (2001), 2161-2169. (d) J. M. Thorpe, R. L. Beddoes, D. Collison, C. D. Garner, M. Helliwell, J. M., Holmes and P. A. Tasker. Angew. Chem. Int. Ed., 38(8), (1999), 1119-1121. (e) E. Bill, C. Krebs, M. Winter, M. Gerdan, A. X. Trautwein, U. Flörke, H.-J. Haupt and P. Chaudhuri. Chem. Eur. J., 3, (1997), 193-201.

[11] G. M. Sheldrick, Acta. Crystallogr., Sect. A: Found. Crystallogr., A46, (1990), 467. 
[12] G. M. Sheldrick, SHELXL-97, A computer programme for crystal structure determination, University of Gottingen, 1997.

[13] P. McArdle, P. Daly and D. Cunningham, J. Appl. Crystallogr., 35, (2002), 378.

[14] R. Dunsten and T. A. Henry. J. Chem. Soc. Trans., 75, (1899), 66.

[15] C. Canada-Vilalta, T. A. O`Brien, E. K. Brechin, M. Pink, E. R. Davidson and G. Christou. Inorg. Chem., 43, (2004), 5505-5521.

[16] C. Canada-Vilalta, E. Rumberger, E. K. Brechin, W. Wernsdorfer, K. Folting, E. R. Davidson, D. N. Hendrickson and G. Christou. J. Chem. Soc. Dalton. Trans., (2002), 4005-4010.

[17] For an extensive family comprising the $\left\{\mathrm{Fe}_{6} \mathrm{O}_{2}(\mathrm{OH})_{2}\right\}^{12+}$ core using a plethora of amino alcohol ligands see: C. Papatriantafyllopoulou, C. M. Kizas, M. J. Manos, A. Boudalis and A. J. Tasiopoulos. Polyhedron. 64, (2013), 218.

[18] Mehrotra, R. C.; Bohra, R. Metal Carboxylates; Academic Press: London, (1983); Chapter 3.2.3. (b) R. D. Cannon and R. P. White. Prog. Inorg. Chem. 36, (1988), 195.

[19] G. Socrates. Infra-Red and Raman Characteristic Group Frequencies. (2004) Wiley VCH Publishing.

[20] F. Birkelbach, M. Winter, U. Flörke, H.-J. Haupt, C. Butzlaff, M. Lengen, E. Bill, A. X. Trautwein, K. Wieghardt and P. Chaudhuri. Inorg. Chem., 33, (1994), 3990-4001.

[21] (a) C. Papatriantafyllopoulou, G. Aromi, A. J. Tasiopoulos, V. Nastopolos, C. P. Raptopoulou, S. J. Teat, A. Escuer and S. P. Perlepes. Eur. J. Inorg. Chem., (2007), 2761-2774. (b) T. Weyhermüller, R. Wagner, S. Khandra and P. Chaudhuri. Dalton Trans., (2005), 2539-2546. (c) P. Chaudhuri, M. Winter, U. Flörke and H.-J. Haupt. Inorg. Chim. Acta., 232, (1995), 125-130.

\section{Graphical Abstract:}

Bulking Up: Sterically demanding oxime and carboxylate ligands combine to aid the selfassembly of hexanuclear $\left[\mathrm{Fe}_{6}\right]$ cages. Magnetic susceptibility measurements reveal dominant antiferromagnetic exchange between the Fe(III) centres. 


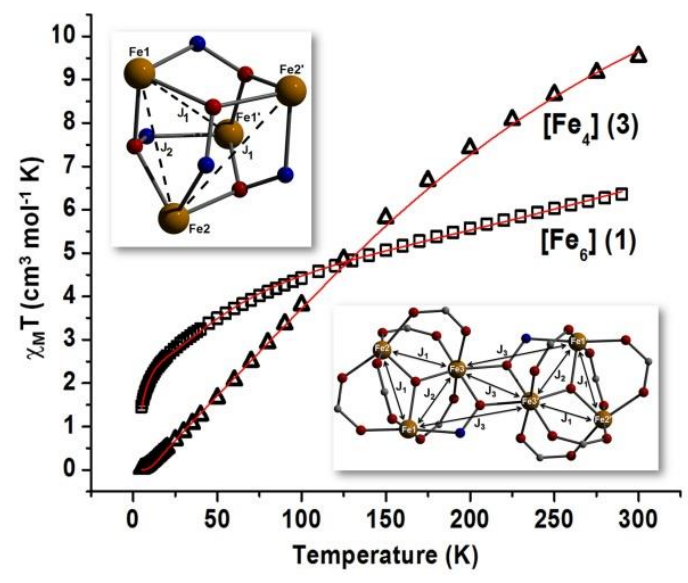

